\title{
Media Education in Kazakhstan: Work Experience
}

\author{
Akhmetova Laila \\ Department of Journalism, Kazakh National University al-Farabi, Kazakhstan
}

Copyright $\bigcirc 2016$ by authors, all rights reserved. Authors agree that this article remains permanently open access under the terms of the Creative Commons Attribution License 4.0 International License

\begin{abstract}
In the Republic of Kazakhstan in 2012 started work on formation of literacy in the field of media education for journalists, educators, and youth. Studied publishing foreign scientists, work experience in different countries, manuals, seminars and workshops, publishes scientific works in the Kazakh and Russian languages, and considers issues of media education in social networks on scientific, methodical and practical conferences. Development of complex measures on improvement of media education in Kazakhstan. Project goal: development of methodical materials on the formation of literacy in the field of media education in Kazakhstan for training target groups and informing the public.
\end{abstract}

Keywords Media, Media Education, Kazakhstan, Youth, Literacy, Education, Training, Information, Teachers, Journalists, NGOs, Civil Society

\section{Introduction}

The problem of training of citizens of the country and, first of all, journalists has arisen with creation of the sovereign state, that is 25 years ago, since the end of 1991 when there was a demolition of the Soviet system. Having become the sovereign country, Kazakhstan needed to change ideology. And it has appeared rather not easy as the Soviet ideology has been introduced in minds of people of nearly 70 years. It was difficult for all generations of people, but it was necessary to learn, first of all, the younger generation of the country to different views, not it to what presented it and teachers who had to train youth.

Practically this process goes still. Though the senior generation which has still met independence of the country has already left, and all have ceased to look back at the Soviet past. At the same time, on many questions the senior generation couldn't pass on positive experience and XX century times. Revival and comprehension of the past has just now begun. And adequate comprehension, that is taking into account both negative, and positive sides. Naturally, there were always many questions in the field of ideology.
There are problems and today.

1. The tasks facing Kazakhstan in the field of training by means of media

2. Transfer of all country to new information technologies

3. Ethics and the principles of modern journalists according to the international standards

4. Work in online mode

5. Efficiency, relevance, novelty of information

6. Use of new technologies in work of media

\section{Methods}

Methodology of comparative-historical research, methodology and equipment of sociological research, social forecasting and design, system and structurally functional approach in a combination to a comparative-historical method and the analysis of statistical data, and also studying of the official documents characterizing policy of the international community and the Kazakhstan state, legal regulation, etc. Use of advantages of interdisciplinary methodology, mathematical and statistical methods and software of processing of social information, the content analysis and the qualitative analysis of documents, methods of comparative researches is supposed also.

\section{The Historical Background of Training by Means of Media in Kazakhstan}

As the system of media education got its direction and development of just over two or three decades ago. Of course, we can speak about the role of cinema, radio, television, press. But, in studying the trends in the 20th century, we are not so much talked about education, how drew attention to the ideological component. In the Soviet Union was preparing ideologists of journalists, film Directors, script writers, writers and specialists in other Humanities. And at the faculty of journalism were the most strict rules, because, at the greatest competition during admission to the profession, was also a serious ideological selection. Only, 
for example, in 1971 for the first time in Kazakhstan were adopted at the journalism faculty of the Germans of the Soviet origin, Crimean Tatars, Chechens and other peoples who once exiled to Kazakhstan. Until this year, they simply didn't accept the documents for the competition, that is, people of certain nationalities simply could not get higher education in the field of media.

Yes, and the distribution of graduates at the time was strict and demanding, and the work went there, which divided the party of Communists. Journalists are the only subject, which were distributed by the Central Committee of the Communist party of Kazakhstan. The same situation existed in the Soviet Union, therefore, to speak of media education for everyone not accounted for. Naturally, there were no experts in this sector. Yes, and the word of the media was not used neither in the everyday life of ordinary people, neither in the scientific community, because it just wasn't there. Before the entire media industry like structure wore a loud and terrible name - media and propaganda, where advocacy was given more space than information.

The first steps media did in the mid 90-ies. It was mentioned very rarely. Basically, specialists from abroad, rarely coming to us. These were journalists, researchers, businessmen, teachers. In the second half of the 90 -ies of the 20th century the term media began to appear in the environment of training and awareness-raising workshops for civil society leaders and journalists.

In the 90th years of the XX century early studies in the field of media already from the point of view of new views on the world have appeared. The Soviet ideology hardly left, practices of what occurred at that time appear. There were failures, but more nevertheless there was an analysis of what was available in the present. Different views were allowed. There are rudiments of democracy and the beginning of civil society.

We get acquainted with words transparency, tolerance. A gender desperately we confuse the tender to the word. And many know that, other word.

In the mid-nineties through the trainings organized by the international funds and embassies of the western countries many leaders of non-governmental organizations are trained in ways of the prevention and resolution of conflicts, fundraising, leadership skills, work with media, the organization and holding press conferences, writing of press releases.

New programs at faculty of journalism in Al-Farabi Kazakh National University are at the same time developed. I am proud of the fact that in the second half of the 90th years of the XX century for the first time in Kazakhstan "The conflict science for journalists", "Management of mass media", "Marketing of mass media", "Psychology in mass media" began to read disciplines.

At the same time at that time passions are raging in the media space. There are conflicts of interests between the senior and young generations, we call them the conflicts of fathers and children, between Kazakh-speaking and Russian-speaking journalism, they began to go the in the way left from each other more and more. There are on an advancing private channels, they represent the worthy competition to public channels. The question of public television is discussed. The Kazakhstan press club, a bit later the National press club and other media public organizations are created.

By 2000 , everyone began to talk about it and at the faculty of journalism and the departments of other universities, where there is a preparation on a specialty "Journalist".

In 2003 the department of management and advertising at faculty of journalism of Al-Farabi Kazakh National University has opened. The journalistic specialty becomes not only creative. It includes economy questions, then management, marketing, advertising. We begin to understand that the economic component in journalism gives freedom of speech and actions. The understanding that journalism is a dangerous profession comes. Legal knowledge and new skills are necessary to protect yourself and the edition.

Moreover, gradually began to learn to speak in the scientific and educational environment professionals: journalists, political scientists, teachers, philologists, psychologists, etc. Today, practically all speak of the media to the word and the word. Most often criticized, disliked, criticize, criticize, but in any case not afraid. For the published critical materials, if they have been confirmed, people fired from work, no matter what you took a place under the sun. This does not exist today. Today, anyone can count himself insulted and sue. And, most of all, wins, taking, for his offended the honor and dignity of millions of tenge. Media began to take the staff whole departments lawyers, without which they cannot exist. The paradox is that sometimes journalists less than lawyers. Yes and salary lawyers in media structures are much higher than journalists. This is a small prehistory media. We are about media education as the problem literally talking three or four years ago. And it's sad, because the world community is moving forward with rapid steps, and we are only beginning to approach this problem. Surprising that media education is perceived as in previous years, as the education of future journalists or as their professional development. When you start to explain and talk about this topic, people like you start to understand, but still dealing with the global theme, your own problems or lobbying on one issue or another, media education is pushed again and constantly on the next day, then when the time. But they had no time. It continued for several years.

Perhaps due to the fact that this question is not active civil sector. Practically it was decided in 90-s and currently are solved now urgent topics of modern times.

\section{Look at This Issue Through the Prism of the International Community}

In the world for over two decades actively promoting the issues of media education in the understanding that has 
developed in modern society, thanks to new information technologies, the widespread use of the Internet, tolerance, transparency, freedom of speech and media. In Canada and Australia media education is already in the age when the child attends kindergarten. In the United States and Europe teach this in school. Russia introduced the education of teachers and as a specialty in higher education in 2000 , and in 2002 introduced the subject in average education link. In Russia published thousands of articles, several dozens of textbooks, there are magazines, defended the thesis and $\mathrm{PhD}$ thesis [1]. In Kyrgyzstan, a more active civil society leaders, which talked about it and carried out various kinds of educational seminars and trainings. In Kazakhstan they went another way [2]. To say that the issues of media education is not engaged, it is impossible, because a number of issues are solved, but the system and gradual introduction of media education in youth.

Let me explain with examples.

For 4 year I leaded a project of the Ministry of education and science of the Republic of Kazakhstan "Development of technologies of media education for the formation of intellectual potential of the country". About the work on the project told on the website of the Kazakh school of socially responsible journalism [3]. A small team was made a certain amount of work: identification of the main functions of network technologies and their influence on the formation of the ideological context of modern culture in the context of the problems of media education. Conceptual bases of formation of media protection. A comparative study of the international experience in the field of media and information literacy. The developed scientific-methodical, scientific-practical recommendations on the formation of media literacy of Kazakhstan youth [4].

Summarize the results of a comprehensive analysis of the current state and prospects of development of modern media education in Kazakhstan in the light of the basic principles of the formation of an intellectual nation. It was carried out a comprehensive study aimed at disclosure of the contents of the basic concepts characterizing the process of the formation of the global information society and the description of the structure of modern information and communication space of Kazakhstan; published analysis of communicative space of Kazakhstan in the context of the problems of media education development. A sociological analysis of the impact of the Kazakhstan media technologies and media on the mass consciousness of the population studied media preferences modern youth audience to take account of the age and ideological peculiarities in the use of technologies of the education, development and concretization of the methodological approaches to media literacy in the environment of Kazakh youth. There is a studying of existing models and technologies of media education and elaboration of recommendations on introduction of principles of media literacy at various levels of the modern educational system of Kazakhstan. Conducted the identification of the main theoretical and methodological concepts in the Kazakh media education, which can be a promising basis for the further successful development of an intellectual nation.

The scientists, members of the project of media education in Kazakhstan acted as the organizers of the international and Republican conferences, actively participated in the joint projects and as participants of conferences, round tables, seminars and trainings. [5] Project participants published articles in foreign and Kazakhstani journals and conference proceedings [6], tutorials "media education in Kazakhstan" and "Press release. The press conference. Experience". [7] Thus, organized and carried out development of methodical materials on the formation of literacy in the field of media education in Kazakhstan for training target groups: journalists, teachers, youth and informing the public.

Except the website we have pages of professionals on Facebook where we communicate - "UNESCO department on journalism and communication" and "Media and Information Literacy (MIL)" [8].

In 2015 the group of authors has published books: "Media education and media literacy: theory, methodology, practice" and "Media and information literacy".

The first book was highly appreciated by UNESCO. The second book published for the first time in Kazakhstan in the form of comics on media and information literacy has been prepared by request of UNESCO in the Kazakh and Russian languages.

Thus we carry out the international standards of UNESCO in the field of training of journalists.

\section{Results}

- educational and methodical materials according to the international standards will be developed;

- the condition of a problem in Kazakhstan in the theory and practice will be studied;

- informing of the public about media education;

- stereotypes concerning media education will be changed;

- $\quad$ target groups are trained;

\section{Conclusions}

Practical significance of the research lies in the possibility of the use of its results in the field of pedagogy, culture, history, journalists, political scientists, teachers, students and graduate students of universities, students.

\section{Recommendations}

The results of the research can be integrated in the educational and training processes. Kazakhstan's experience in media education can be represented in the international educational structures, the Bologna process in the CIS, countries of Central Asia. 


\section{REFERENCES}

[1] Fedorov A.V. Media education: history, theory and methods. Rostov CWR, 2001. - 708 p.; Sharikov, A. Media education: international and Russian experience. - M: Publishing house of the Academy of pedagogical Sciences, 1990. $66 \mathrm{p}$.

[2] Media education in Kazakhstan: experience //II int. scientific-practical conference "Theory and practice of teacher training in Central Asia", Bulletin of Kyrgyz National University. J. Balasagyn. Issue 1. Pedagogical science. 2013.b - 47 printed sheets, 750p. /88-92/

[3] The website of the Kazakhstan school of socially responsible journalism - http://unesco-kaznu.ucoz.kz//

[4] New knowledge and the conservation of materials through the introduction and use of information-digital resources. // Materials of International scientific-practical conference "Studying, preservation and popularization of the intangible assets on a way of development of the Kazakhstan society of knowledge", December 11, 2013 - Almaty, 220 p. /128-130/

[5] Conferences, seminars, round tables: carrying out of the int. round table "media literacy society: problems and prospects", devoted to the Day of press freedom 3.05.2012; participation in the Internet-conference " the Impact of new media on the creation and behavior of young people: a multidisciplinary approach" - Tomsk, Russia // http://connect-universum.com/ page/documents/ru/- 2012; organization of a seminar on media education of the leaders of trade unions of builders and forestry ( 9 countries) 2012; international seminar for journalists "Ethical principles in highlighting the issues of childhood" - UNICEF, Almaty, 2012; participation in the Meeting of the ODIHR/OSCE on the human dimension of 2012. - Warsaw, Poland. 23.09.-5.10.2012. In the framework of the meeting prepared five thematic reports; presentation at the international scientific seminar on the environment in the

Kyrgyz National University. Balasagyn (Bishkek, Kyrgyzstan) on the topic "media education in ecology" 2013.

[6] Akhmetova L.S. Gender, media literacy and media education: problems and prospects. //Gender aspects of social modernization. Materials Of International scientific-practical use. Conf. - Almaty, 356 S. - S. 287-291; Akhmetova L.S. "New media in Kazakhstan: experience, problems, prospects" (in Russian and in English) - http://connect-universum.com/ blog/connectuniversum/53.html; Akhmetova L.S. Indicators of media development: enhancing the potential of the media. Training and journalism education. //Forward to a free press in Central Asia. 20 years later. Proceedings of the conference. UNESCO. - Almaty: Kazakhstan, the UNESCO Office in Almaty, 2013. 348 p. //219-225; Lifanova T.U., Verevkin A.V. Theoretical-methodological introduction to the concept of media education // Innovative development and relevance of science in modern Kazakhstan: materials of international scientific conference. - Almaty: Sanat, 2012 - p. 275-281; and other

[7] Akhmetova L.S., Verevkin A., Lifanova S., Shorokhov D. Media education in Kazakhstan. Educational-methodical aid. - Almaty: Kazakh University, 2013. - 252 S.; Akhmetov PS Press release. The press conference. The experience. - A training manual. 2 ed. - Almaty: Kazakh University, 2013. $88 \mathrm{p}$.

[8] Кафедра ЮНЕСКО по журналистике икоммуникации -https://www.fhttps://www.facebook.com/groups/295672907 171311/acebook.com/groups/844954595543881/; Media and Information Literacy (MIL)-https://www.facebook.com/grou ps/295672907171311/

[9] Ахметова Л.С., Веревкин А.В., Лифанова Т.Ю. Медиаобразование и медиаграмотность: теория, методология, практика. - Алматы: Қазақ университеті. 2015. - 155 с.; 1. Ахметова Л., Шорохов Д., Ниязгулова А. Медийная и информационная грамотность. - Алматы, 2015. - Бюро ЮНЕСКО в Алматы.- 35 с. 